\title{
Interface Stability During Rapid Directional Solidification
}

\section{Citation}

Hoglund, David E., and Michael J. Aziz. 1992. Interface stability during rapid directional solidification. In Kinetics of phase transformations: Proceedings of the materials research society symposia 205, eds. M. O. Thompson, M. Aziz, G. B. Stephenson, and D. Cherns, 325-329. New York: Materials Research Society.

\section{Permanent link}

http://nrs.harvard.edu/urn-3:HUL.InstRepos:3660739

\section{Terms of Use}

This article was downloaded from Harvard University's DASH repository, and is made available under the terms and conditions applicable to Other Posted Material, as set forth at http:// nrs.harvard.edu/urn-3:HUL.InstRepos:dash.current.terms-of-use\#LAA

\section{Share Your Story}

The Harvard community has made this article openly available. Please share how this access benefits you. Submit a story.

Accessibility 
INTERFACE STABILITY DURING RAPID DIRECTIONAL SOLIDIFICATION

David E. Hogftund and Michiel J, Aziz

Division of Applied Sciences, Harvard University, Cambridge, MA 02138

\section{ABSTRAC'T}

At the solidification velocities observed during pulsed laser annealing, the planar interface between solid and hiquid is stabilized by capillarity and nonequilibrium effects such as solute trap. ping. We used Rutherford backscattering and electron microscopy to determine lic nonceputibritum partition coefficient and critical concentration for breakdown of he planar interface as a function of mterface velocity for Sn-implanted sisicon. This allows us to test the applicability of the MusllinsSckerkit stability theory to interfates not in local equilibrium and to test the Coriell-Sckerkit and other theorics for oscillatory instibilitics.

\section{INTRODUCTION}

During steady-state solidification of a single-component melt, a planar solid-licutid inlerfatce will remiain stable ats long as heat is removed through the solid. If the interface is in locial equilibrium, then the solid stays below the melting iemperature, the interfice at the melting temperiltare, and the liquidl above the melting temperature. Since the liquid is not undercooled, the interlitce is stable.

The statbitity criterion for a two-component melt is more complicated. Tiller $e t$ al. [1] intilyzed the effect of soltte preferentiatly partitioning into the liquid. They slowed that for any straight-line licpuiders, there exists a critical concentration of solute in the bulk liģuid such that the interfice is unstable. Solute rejected by the interface creates a concentration gradient in the liquid layer next to the interface. The concentration gradient causes the liquid ahead of the interface to be undercooled with regard to the composition-dependent liquidus temperature despite being at a higher temperature than the interface. This is the basis of the constitutional supercooling condition.

Later, Mullins and Sekerka [2] used linear perturbation antalysis to evaluate interface stability. They started their analysis with an unperturbed planar interface in lecal equilibrium moving at constant velocity. Then they catculated the time dependence of the amplitude of an infintitesinial sinusoidal perturbation imposed on the interface. Since the perturbation curves the interface, dicy tosk capillarity into account and found that it had a stabilizing effect, especially at high solidification velocities. The effect is strong enough that for any concentration of solute in the bulk linguid, the interface is stable if the velocity is high enough. A hight velocity allows linte time for lateral difthsion of solue, so no large scale perturbations an fom. Small seale perturbations do have lime to form, bue these are the pentirbations that capillarily resists most strongly. This is the busis for the Mullins-Sekerka absolute stability linit. For high velocities, the absolute stability limit reduces to the following simple form:

$$
\mathrm{C}_{\infty}=\frac{\mathrm{k}^{2} \mathrm{~T} M \Gamma v}{(\mathrm{k}-1) \mathrm{m} \mathrm{D}_{\mathrm{L}}}
$$

where $\mathrm{C}_{\infty}$ is the critical bulk concentration in the liquid to caluse interface breakdown, $\mathrm{k}$ is the partition coefficient (ratio of the solute concentration in the growing solid to that in the licpid at the interface), $T_{M}$ is the melting point of pure solvent, $\Gamma$ is the canpillarity constant (ratio of surfitce tension to heat of fusion), $v$ is the interface velocity, $m$ is the slope of the straight-line liquidus, and $D_{L}$ is the diffusivity of solute in the batk of the liquid.

The Multins-Sekerki analysis assumes local equilibrium at the the intefface. This assumption is least likely to hold at velocities where equation (1) is most likely to be valid. The limit of interface stibility should be sensitive to nonequilibrium effects because the suppressed partitioning [.] or "solute trapping" associated with nonequilibrium solidification ought to stabilize the interface.

Mat. Res. Soc. Symp. Proc. Vol, 205. ")1992 Materlais Aesearch Soclely 
Early tests of interface stability under nonequilibrium conditions [4-6] showed that stabilization did indeed occur. Now that the kinetic undercooling function in pure silicon [7-9] and solute trapping function for various dopants in silicon [10-12] have been measured, it is possible to incorporitte

nonequilibrium effects systematically into stability theory.
Aziz and Kaplan [13] have proposed a model for the interface response functions callecl the "continuous growth model without solute drag." For solute trapping in the dilute solution regime, the model gives

$$
k(v)=\frac{\left(v / v_{D}\right)+k_{c}}{\left(v / v_{D}\right)+1}
$$

where $k$ is the nonequilibrium partition coefficient, $k_{e}$ is the equilibrium partition coefficient, $v$ the interface velocity, and $v_{D}$ the diffusive velocity. Using the continuous growth model and assuming a dilute solution, a straight-line equilibritum liquidus and solidus, and a solidification velocity mucl less than the maximum solidification velocity at infinite driving force, Boettinger has derived a simple expression [14] for the slope of the kinetic liquidus,

$$
m(k(v))=m_{\mathfrak{c}} \times\left\{1+\frac{k_{\mathfrak{c}}-k\left(1-\ln \frac{k}{k_{\mathfrak{c}}}\right)}{1-k_{\mathfrak{c}}}\right\} .
$$

where $k$ is the nonequilibrium partition coefficient, $k_{c}$ is the equilibrium partition coefficient, and $m_{c}$ is the slope of the equilibrium liquidus. Substituting the partition coefficient of equation (2) ank the liquidus slope of equtation (3) into the Mullins-Sekerka result (not just equation (1), but the full solution) yields a thermodynamically consistent formulation of nonequilibrium linear stability theory.

We recently reported [15] the first cutantitative test of stability theory, using Sn-implanted Sion-sapphire (SOS) samples. However, the large number of extended defects in these samples not only made identification of the cell walls difficult but also might have influenced the breakdown of the plathar interface. Here we report similar measurements performed on bulk single erystal $\mathrm{Si}(100)$. We compare our measurements of the onset of instability to the theory. Since the key parameters in the theory have already been measured, this constitutes a guantitative test with no free parameters.

\section{EXPERIMENT}

Wafers of (100) silicon were implanted with $165 \mathrm{keV}{ }^{120} \mathrm{Sn}^{+}$at doses of 1 and $2 \times 10^{16} / \mathrm{cm}^{2}$. Samples were melted with a $30 \mathrm{~ns}$ FWHM XeCl $(308 \mathrm{~nm})$ excimer laser pulse. Preheating samples with a $80 \mathrm{~W} \mathrm{CO}_{2}$ laser just before firing the excimer laser allowed us to control the thermill conductivity and thermal gradient in the material and thereby extend the range of solidification velocities to lower velocities. Surface melt durations were measured using the transient reflectivity of a low power Ar ion laser. Since for our samples the melt duration as a function of laser fluence wass close to that of pure bulk silicon, we could use well calibrated heat flow-sinulations of pulsed lats melting of pure silicon [16] to obtain melt depths and solidification velocities for our samples.

After solidification, the Sn concentration-depth profile was measured using Rutherford Backscattering Spectrometry (RBS). Since nonsubstitutionality of dopants bas been correlated with interface breakdown [17], we also performed ion channeling analysis. Mgure 1 shows data for onc sample. We initially assumed that the interface broke down at the depth where the concentration of nonsubstitutional Sn became appreciable. The total concentration of Sn at that depth was tiken to be the critical concentration for breakdown. This is exact for steady state solidification. For exilmple, the interpretation of Figure 1 is that the interface was stable from $3300 \lambda$ (the maximum melt concentration at $1500 \AA$, about 0.7 atomic percent $\mathrm{Sn}$.

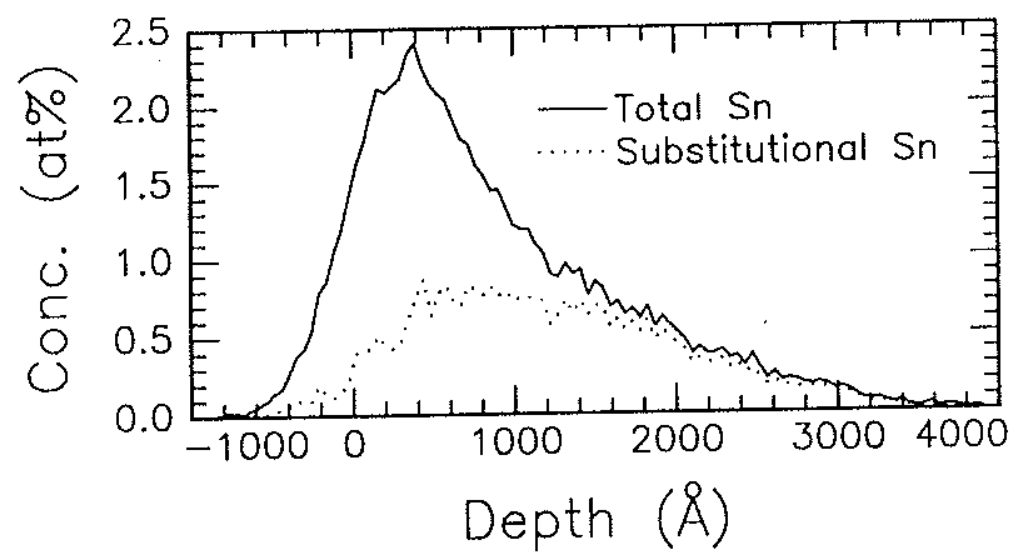

Figure 1: RBS /channeling data for Sn-implanted bulk Si(100) after pulsed laser melting

DISCUSSION

Figure 2 shows our data. It also shows a full numerical solution to the Mullins-Sekerka theory ather than the high velocity limit of equation (1). For the dashed curve, we assumed that $k$ itnd $m$ bad their equilibrium values. For the solid curve, we used the $k$ of equation $(2)$ and the $m$ of elutition (3). The equilibrium partition coefficient is $k_{e}=0.016$. The diffusive velocity, $v_{D}=17 \mathrm{ml} / \mathrm{s}$, and the liquid diffusivity, $\mathrm{D}_{\mathrm{L}}=2.5 \times 10^{-4} \mathrm{~cm}^{2} / \mathrm{sec}$, were taken from solute trapping experiments [15]. Values of other thernophysical parameters not taken from Cahn, Conell, and Boeltinger (is] ate: capillarity factor $T_{\mathrm{M}} \Gamma=1.3 \times 10^{-7} \mathrm{Km}$ obtained from homogeneous nucleation experintent [19]; and slope of the equilibrium liquidus $m_{c}=-460 \mathrm{~K}$ [20]. The temperature gradient in the liculd was estimated to be $2 \times 10^{4} \mathrm{~K} / \mathrm{m}$ from heat flow calculations. The temperature gradient in the solid was approximated by the product of the velocity and the latent heat divided by the thermal conductivity in the solid. Although these estimates are reliable, the predictions are highly

Thery and for sorimente no adjustable parameters in cher silicor-onthe comparis are in progress. The cell size, measured sapphire samples (1.). Crossin pion TEM is under way to verify that the interface did break down at the position inferred by RBS/channeling. Finally we should consider that there might be a delay in this non-steady-state expering berwe that all of our data lie slightly above the curve predicted by the theory). Both the second and third hat possible tat the surat due to heterogencous nucleation. In this case the theoretical curve in Fig. 2 would be moved upwards as equation (1) shows.

We have also considered theories for oscillatory instabilities such those developed by Coriel nd Sekerka [21] and Merchant and Davis [22]. It now seems that $\mathrm{Si}(\mathrm{Sn})$ is not a good system for studying oscillatory instabilities because the crystal/melt interface is too sluggish. According to studying os inter ins always become susceptible to steady instabilities before oscillating ones. 


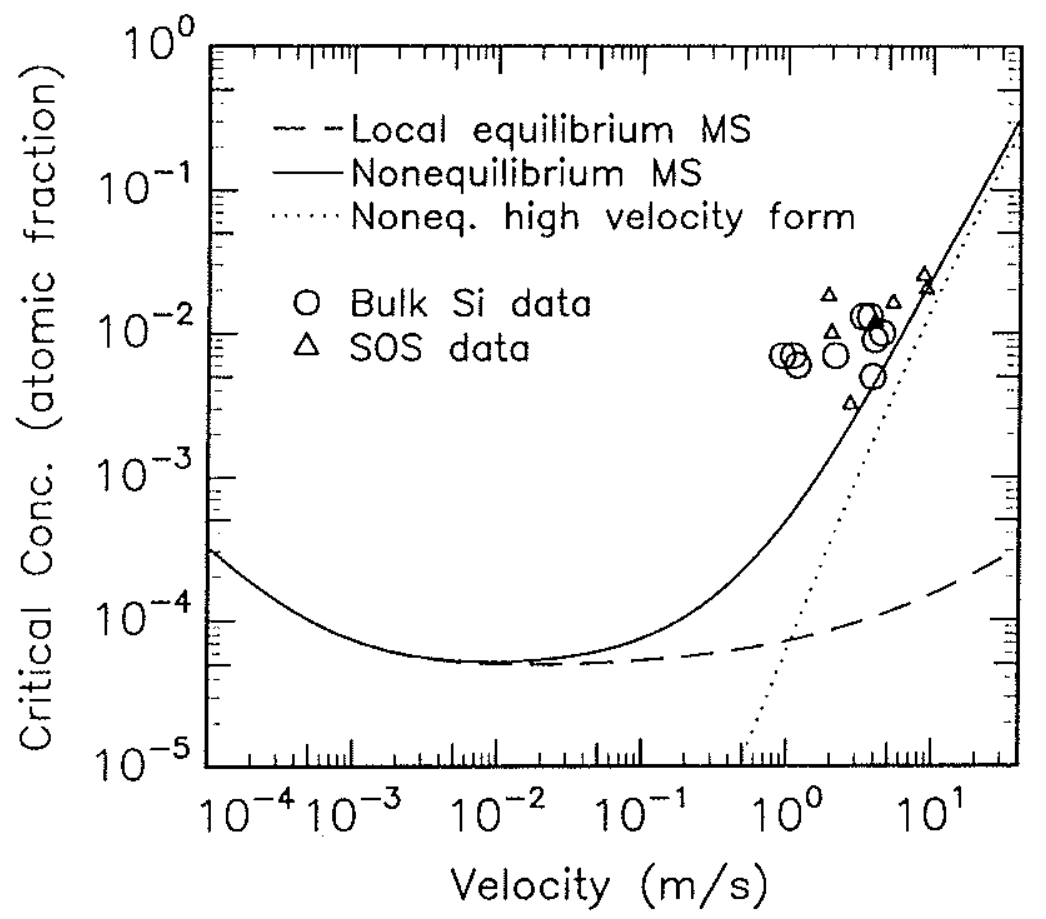

Figure 2: Critical concentration above which cellular breakdown of planar interface occurs Curves: (- - ) Mullins-Sekerka theory assuming local equilibrium; $(-\rightarrow$ Mullins-Sekerki theory assuming $k(v)$ and $m(k(v))$ given by equations (2) and (3); (…) Equtation (1), simplitice cquations (2) and (3).

\section{ACKNOWLEDGEMENTS}

We are grateful to J.Y. Tsao, P.S. Peercy, S.R. Stiffler and M.O. Thompson for collaborittion, and to C. Hayzelden for instruction in microscopy, in the SOS study. We thank S.R. Coriell for assistance with the numerical solution to the stability equations. Samples were implanted at the Surface Modification and Characterization Facility at Oak Ridge National Laboratory. Work Harvard was supponed by the DOE through DE-FG02-89ER45401 (J.B. Dirby).

\section{REFERENCES}

1. W.A. Tiller, K.A. Jackson, J.W. Rutter, and B. Chalmers, Acta Metall. 1, 428 (1953).

2. W.W. Mullins and R.F. Sekerka, J. Appl. Phys. 35, 444 (1964).

3. J.C. Baker and J.W. Cahn, Acta Metall, 17, $575(1969)$

4. J. Narayan, J. Appl. Phys. \$2, 1289 (1981).
5. A.G Cullis, D J rlurle, HIC Webber, N.G. Chew, J.M. Poate, P. Baeri, and (G. Fold, Appl Phys Lell. $38,642(1981)$

6. S.U. Campisino and J.M Poute, Appl. Phys, Lett. 47, 485 (1985)

7. G. Galvin JW Mayer and P.S. Peercy, Appl. Phys. Lell 46, 644 (1985)

8. Thes. Symp. Proc. 35, 18 (1985).

OZ Tischler, and D.M Mills, J. Mater. Res. 1144 (1986)

. W. Whompson, P.S. Pecrcy, and C.W. Phys. Rev. Lell. 50. 2489 (1986)

. White, Phys. Rev. Lett. 57, 2675 (1986).

12. M. Goldman and M J Aziz J. Mater. Res. 2, 524 (1987).

3. MJ Azizand T Kaplan Acta Metall 36,2335 (1988).

14. WJ Boetinge and S R Coriell, in Science and Technology of the Undercooled Mels: Ravid Solidification Mares, and C.M. Adams (Nijhoff Publishers, Dordrecht, the Netherlands, 1986), p. 81 .

15. D.E Hoglund M.J. Aziz, S.R. Stiffler, M.O. Thompson, J.Y. Tsao and P.S. Peercy, J. Crystil Growth in press (1990)

6. M. A W White, J. Narayan, and B. Stritzker, in Enerey Beam-Solid Intcractions iand Transient Thermal Processing, edited by V.T. Nguyen and A.G. Cullis (Editions de Physique, Paris, 1985), p.231.

17. C.W. White, B.R Appleton, B. Stritzker, D.M. Zehner, and S.R. Wilson, Mater. Res. Soc. Symp. Proc. 1,59 (1981).

18. JW Cahn, S.R. Coriell, and J.W. Boettinger, in Laser and Eleciron Beam Processing of Materials edited by C.W. White and P.S. Pcercy (Academic Press, New York, 1980), p. 89.

19. P.V. Evans, G. Devaud, T.F. Kelly, and Y.-W. Kim, Acta Metalt. 38, 719 (1990).

20. CD. Thumond and M. Kowalchik, Bell System Technical Joumal 32, 169 (1960)

21. S.R. Coriell and R.F. Sekerka, J. Crystal Growth 61, 499 (1983).

22. G.J. Merchant and S.H. Davis, Acta Metall. 38, 2683 (1990).

23. S.R. Coriell (private communication).

24. G.J. Merchint and S.H. Davis (private communication) 